\title{
Analysis of the Essential Oils of Leaves and Stems of Crassocephalum crepidioides Growing in South Western Nigeria
}

\author{
Owokotomo, I. A. (Corresponding author) \\ Department of Chemistry, Federal University of Technology \\ PMB 704, Akure, Nigeria
}

Tel: 234-803-542-6559Ｅ-mail: kunleowokotomo@yahoo.com

Ekundayo, O.

Department of chemistry, University of Ibadan, Ibadan, Nigeria

Tel: 234-803-064-3828Ｅ-mail: o.ekundayo@yahoo.com

Oladosu, I. A.

Department of chemistry, University of Ibadan, Ibadan, Nigeria

Tel: 234-803-656-0184Ｅ-mail: ai.oladosu@mail.ui.edu.ng

Aboaba, S. A.

Department of chemistry, University of Ibadan, Ibadan, Nigeria

Tel: 234-803-801-1394Ｅ-mail: sa.aboaba@mail.ui.edu.ng

Received: June 9, 2011

Accepted: June 23, $2011 \quad$ Published: April 1, 2012

doi:10.5539/ijc.v4n2p34

URL: http://dx.doi.org/10.5539/ijc.v4n2p34

\begin{abstract}
The essential oils from fresh leaves and stems of Crassocephalum crepidioides (Asteraceae) growing wild in south western Nigeria and used as food supplement by the local population were extracted. The essential oils were extracted using Clevenger- type hydrodistiller and analysed by GC- MS. The percentage yields of oils were $0.12 \% \mathrm{v} / \mathrm{w}$ and $0.09 \% \mathrm{v} / \mathrm{w}$, respectively. The essential oils of the leaves contained $\alpha$-caryophyllene $(10.29 \%)$, $\beta$-cubebene (13.77\%) and $\alpha$-farnesene (13.27\%) as major constituents while the dominant constituents of the stems oil were thymol (43.93\%), $\alpha$-caryophyllene (15.16\%) and 4-cyclohexybutyramide $(20.94 \%)$.
\end{abstract}

Keywords: Essential oil, Crassocephalum crepidioides, Hydrodistillation, South western Nigeria

\section{Introduction}

Crassocephalum crepidioides (Asteraceae) known locally in south western Nigeria as "Ebolo" is a popular food supplement in Nigeria (Agbogidi, 2010). The plant grows in large quantity as undercover in tree crop plantations (Dairo et al., 2007). The edible leaves and stems are used to treat indigestion or as laxative, as purgative and remedy for lever problem (Fowomola et al., 2005; Ayodele, 2007). The antioxidant activity of Crassocephalum crepidioides has been demonstrated. The plant extracts showed marked antioxidant activity in linoleic acid model systems (Odukoya et al., 2007).

Free radical scavenging and Hepatoprotective actions of Crassocephalum crepidioides has also been demonstrated in Japan where the plant grows wildly in the Okinawa Islands and well known among folks as remedy for acute hepatitis and fever (Yoko Aniya et al., 2005). Also, extracts from the plant have been shown to possess cancer chemo preventive actions and anti-inflammatory properties (Chia- Chung Hou et al., 2007).

The chemical constituent of the ethanol extracts and the lipid peroxidation inhibitory effect of $C$. Crepidiodes from Nigeria has been investigated (Salawu et al., 2006). The result reveals the presence of phenyl acetic acid, 
Vanillic acid, protocatechiuc acid and caffeic acid. The plant extracts also showed high tendency to inhibit lipid peroxide formation and thus capable of preventing its numerous pathological effects.

Literature reports on the essential oils composition of C. cepidioides are scant. However, Zollo et al. (2000) reported that the essential oils of $C$. crepidiodes and six other species of the same genus from Cameroon were composed mainly of $\alpha$-phellandrene, p-cymene, pinene, myrecene, limonene and E- $\beta$-ocimene as the major constituents.

Essential oils of a large number of plants possess useful biological, pharmacological and therapeutically activities and are commercially important compounds. Their utilization in the various industries is influenced by the nature of their constituents (Ekundayo, 1986).

It is known that the essential oils composition pattern could be affected by the geographical and climatic conditions(Arras et al., 2009), and to the best of our knowledge there has been no previous report on the chemical compositions of essential oils of $C$. crepidioides from Nigeria. On these bases, we investigate the essential oils of leaves and stems of Crassocephalum crepidioides indigenous in south western Nigeria.

\section{Materials and Methods}

\subsection{Plant material and Isolation of Essential Oils}

The plant materials used for this experiment were harvested at an abandoned cocoa plantation behind The Federal University of Technology, Akure, Ondo state, Nigeria. The identification was done by experts at the Forest research institute of Nigeria (FRIN) where Voucher specimen was deposited in the Herbarium. Fresh plant parts were carefully separated, washed and then subjected to hydro- distillation separately for 1-2hrs using a Clevenger-type glass apparatus, according to British Pharmacopoeia (1980) specification, but modified with graduated column to enable direct estimation of oil yield. The weight of fresh plant material was $1 \mathrm{Kg}$ for each plant part. The oil yield was calculated in percentage of volume per weight of plant samples. The oil samples were stored in air-tight containers at $0{ }^{\circ} \mathrm{C}$ before going for GC-MS analysis without any further treatment.

\subsection{Gas Chromatography/mass Spectrometry Analysis}

The essential oils were analysed using GC-MS Agilent 6890N GC Coupled with MS-5973-634071 Series. The capillary column type was DB-1MS [30.0 m (length) X $320.00 \mu \mathrm{m}$ (diameter) X $1.00 \mu \mathrm{m}$ (film thickness)]. The carrier gas was Helium at constant flow rate of $1.0 \mathrm{ml} / \mathrm{min}$ and average velocity of $37 \mathrm{~cm} / \mathrm{s}$; the pressure was 0.78 psi. The initial column temperature was set at $100{ }^{\circ} \mathrm{C}$ (hold for $2 \mathrm{~min}$ ) to the final temperature of $250{ }^{\circ} \mathrm{C}$ at the rate of $5{ }^{\circ} \mathrm{C} / \mathrm{min}$, Volume injected was $1.0 \mu \mathrm{L}$ and split ratio was $50: 1$.

The total chromatogram was auto-integrated by ShemStation and the constituents were identified by comparison with published mass spectral database (NIST02.L) and data from literature.

\section{Results and Discussion}

\subsection{Percentage Yield}

The percentage yield of essential oil of leaves and stems of $C$. crepidioides were $0.12 \%$ and $0.09 \% \mathrm{v} / \mathrm{w}$ respectively.

\subsection{Chemical Constituents}

A total of thirty-five compounds were identified in the essential oils of the leaves and stems of C. crepidioide. The stems essential oil yielded just five compounds against thirty-two compounds obtained from the leaves essential oils. Thymol (43.93 \%), 4-cyclohexyl butyramide (20.94\%) and $\alpha$-caryophyllene (15.16 \%), $\alpha+\beta$-caryophyllene $(10.72 \%)$ and 6-Phenyl dodecane $(9.25 \%)$ were the compounds present in the stems oil, while $\beta$-cubebene ( $13.77 \%$ ), $\alpha$-farnesene (13.27\%) and $\alpha$-caryophyllene $(10.29 \%)$ form the major constituents of the leaves essential oil. Other notable constituents of the leaves essential oil were Phytol (6.30\%), caryophyllene (6.05\%), Z-1-(1-butenyl) aziridine (3.73\%) and cis- $\beta$-farnesene (3.06 \%). $\alpha$-caryophyllene was the only constituent common to both the stems and the leaves essential oils of $C$. crepidiodes. Thus the leaves serve as the major reservoir of chemical compounds in the plant. Complete list of compounds obtained from the stems and leaves of $C$. crepidioides are summarised in Table 1.

\section{Conclusions}

In conclusion, the essential oils of Crassocephallum crepidiodes indigenous in south western Nigeria afforded a plethora of compounds of which thymol, $\alpha$-caryophyllene, $\beta$-cubebene, $\alpha$-Farnesene and 4 -cyclohexybutyramide were the major constituents. The study reveals that the composition of the oils differ from the earlier report from 
Cameroon and may therefore be regarded as a different chemotype. C. crepidiodes growing in South Western Nigeria may be utilised as a natural source for thymol which is known to possess antimicrobial activity.

\section{References}

Agbogidi, O. M. (2010). Ethno-botanical survey of non-timber forest products in Sapele local government of Delta State, Nigeria. African Journal of Plant Science, 4(6), 183-189.

Arras, G., \& G. E. Grella. (1992). Wild thyme, Thymus capitatus, essential oil seasonal changes and antimycotic activity. Journal of Horticultural Science, 67, 197-202.

Ayodele, A. E. (2007). The medicinally important leafy vegetables of South Western Nigeria. [Online] Available: http://www/.siu.edu/webl/leaflets/ayodele.htm

British pharmacopoeialI, 1980. 109, H M, Stationary Office, London.

Chia Chung Hou, Yi-Ping Chen, Jyh-Horng Wu, Chi-Chang Huang, Sheng-Yang Wang, Ning-Sun Yang, \& Lie-Fen Shyur. (2007). A Galactolipid possesses Novel Cancer Chemo preventive Effects by Suppressing Inflammatory Mediators and Mouse B16 Melanoma. Cancer Research, 67, 6907-6915. http://dx.doi.org/10.1158/0008-5472.CAN-07-0158

Dairo, F. A. S., \& Adanlawo, I. G. (2007). Nutritional quality of Crasocephalum crepidioides and Senecio biafrae. Pakistan Journal of Nutrition, 6(1), 35-39. http://dx.doi.org/10.3923/pjn.2007.35.39

Djah F. Malam, \& Dahho F. R. Neuba. (2011). Traditional practices and medicinal plants use during pregnancy by Anyi-Ndeye women (Eastern Cote d' Ivore). African Journal of Reproductive Health, 15(1), 85-94.

Ekundayo Olusegun. (1986). Essential oil composition of some Nigerian medicinal plants. Progress in Essential Oil Research. C. Walter de Gruyter \& Co. Berlin, New York - Printed in Germany.

Fowomola, M. A., \& A. A. Akindahunsi. (2005). Protein quality indices of sand box (Hura-crepitans) seed. J. Fd. Agri. Environ., 3, 16-19.

Odukoya, O. A., Inya-Agha, S. A., Segun. F. A., Sofidiya, M. O., \& Ilori, O. O. (2007). American Journal of Food Technology, 2(3), 169-175.

Salawu, S. O., Akindahunsi, A. A., \& Cornuzzo, P. (2006). Chemical composition and in vitro antioxidant activities of some Nigerian vegetables. Journal of Pharmacology and Toxicology, 1(5), 429-437. http://dx.doi.org/10.3923/jpt.2006.429.437

Yoko Aniya, Tomoyuki Koyama, Chika Miyagi, Maanami Miyahira, Chiho Inomata, Shizuka Kinoshita, \& Toshiol Chiba. (2005). Free Radical Scavenging and Hepatoprotective Actions of the Medicinal herb. Crassocephalum crepidioides from the Okinawa Islands. Biol Pharm. Bull, 28(1), 19-23. http://dx.doi.org/10.1248/bpb.28.19

Zollo, P. H. A., kuiate, J. R., Menut, C., \& Bessiere, J. M. (2000). Aromatic plants of tropical central Africa. XXXVI. Chemical composition of essential oils from seven Cameroonian Crassocephalum species. Journal of essential oil research, 12(5), 533-536. 
Table1. Chemical composition of the essential oil of leaves and stems of Crassocephallum crepidioides

\begin{tabular}{|c|c|c|c|}
\hline \multirow[t]{2}{*}{ Chemical compounds } & \multirow{2}{*}{$\begin{array}{c}\text { Retention } \\
\text { Times (Min) }\end{array}$} & \multicolumn{2}{|c|}{ Percentage composition (\%) } \\
\hline & & Leaves & Stems \\
\hline m-tert-Butyl phenol & 2.25 & 2.44 & - \\
\hline P-Myrecene & 2.41 & 0.80 & - \\
\hline $\begin{array}{l}\text { 1-Methyl-2-(1-methylethyl)- } \\
\text { 3-(1-methylethylidene)cyclopropane }\end{array}$ & 2.47 & 1.08 & - \\
\hline Myrtenol & 2.53 & 2.78 & - \\
\hline 2,6-Dimethyl-3,5,7-octatriene-2-ol & 3.09 & 2.45 & - \\
\hline 2-lsopropylidene-3-methylhexa-3,5dienal & 3.67 & 1.06 & - \\
\hline Z-1-[1-butenyl]aziridine & 3.80 & 3.73 & - \\
\hline Thymol & 4.08 & - & 43.93 \\
\hline 3-Methylene-p-menth-8-ene & 5.37 & 1.12 & - \\
\hline Artemisia triene & 5.56 & 2.78 & - \\
\hline Copaene & 5.70 & 1.71 & - \\
\hline 2-Dodecanone & 5.80 & 2.78 & - \\
\hline$\beta$-Elemene & 5.94 & 2.24 & - \\
\hline Caryophyllene & 6.40 & 6.05 & - \\
\hline$\alpha$-Caryophyllene & 7.00 & 10.29 & 15.16 \\
\hline$\alpha+\beta$-Caryophyllene & 7.12 & - & 10.72 \\
\hline cis- $\beta$-Farnesene & 7.14 & 3.06 & - \\
\hline$\beta$-Cubebene & 7.51 & 13.77 & - \\
\hline 2-Tridecanone & 7.73 & 2.53 & - \\
\hline$\beta$-Elemene & 7.93 & 3.17 & - \\
\hline$\alpha$-Fernesene & 8.15 & 3.27 & - \\
\hline$\delta$-Cadinene & 8.32 & 1.35 & - \\
\hline$\gamma$-Elemene & 8.88 & 1.83 & - \\
\hline 3,7,11-Trimethyl-1,6,10-dodecatrien-3-ol & 9.11 & 2.89 & - \\
\hline Caryophyllene oxide & 9.23 & 2.18 & - \\
\hline Humulene epoxide II & 9.17 & 1.07 & - \\
\hline$\alpha$-Santalol & 10.15 & 0.71 & - \\
\hline Z-Ocimene & 10.32 & 2.35 & - \\
\hline $\begin{array}{l}\text { 2-Methylene-6,8,8-trimethyl } \\
\text { tricycle[5.2.2.0(1,6)]undecan-3-ol }\end{array}$ & 11.21 & 1.07 & - \\
\hline 2,6,8-Trimethyl decanoic acid methylester & 13.65 & 0.73 & - \\
\hline 6-Phenyl dodecane & 14.50 & - & 9.25 \\
\hline 1,19-Eicosadione & 14.99 & 0.85 & - \\
\hline Phytol & 16.50 & 6.30 & - \\
\hline n-Hexadecanoic acid & 17.14 & 1.06 & - \\
\hline 4-Cyclohexylbutyramide & 23.28 & 20.94 & - \\
\hline
\end{tabular}

